\title{
Effects of Transformational Leadership, Organisational Learning and Technological Innovation on Strategic Management Accounting in Thailand's Financial Institutions
}

\author{
Kornchai Phornlaphatrachakorn*
}

\begin{abstract}
Manuscript type: Research paper.

Research aims: This study aims to investigate the effects of transformational leadership, organisational learning and technological innovation on strategic management accounting in Thailand's financial institutions.

Design/Methodology/Approach: Data were collected from 141 financial institutions in Thailand through a questionnaire survey. Hierarchical multiple regression analysis is conducted to examine the relationships.

Research findings: The findings indicate that transformational leadership, organisational learning and technological innovation positively influence strategic management accounting. The results also indicate a positive relationship between strategic management accounting and firm performance.

Theoretical contributions/Originality: This study expands on existing literature by investigating the role of transformational leadership, organisational learning and technological innovations as antecedents to the implementation of strategic management accounting. It thus extends on the applicability of strategic management accounting in helping financial institutions in Thailand to gain superior performance.
\end{abstract}

\footnotetext{
* Kornchai Phornlaphatrachakorn is an Associate Professor of accounting at the Mahasarakham Business School, Mahasarakham University, Thailand. Email: phapruke.u@acc.msu. ac.th, markarlington@hotmail.com
}

https://doi.org/10.22452/ajba.vol12no1.6 
Practitioner/Policy contributions: The results of this study suggest that executives of financial firms need to pay attention towards building and developing transformational leadership, organisational learning and technological innovation for strategic management accounting implementation. This can be achieved by leveraging on the firm's competencies, capabilities, resources and assets. In other words, strategic management accounting can serve as a tool for organisations to gain a competitive edge in today's dynamic business environment, thereby fulfilling firm performance.

Research limitations/Implications: To increase the generalisability of this study, future research needs to collect data from a different set of population or country. This will help to expand on the database of the financial businesses throughout the world.

Keywords: Transformational Leadership, Organisational Learning, Technological Innovation, Strategic Management Accounting, Firm Performance JEL Classification: M41

\section{Introduction}

The prevalence of globalisation and the rapidly evolving technology which contribute to today's dynamic business environment is forcing financial institutions to undergo changes and to respond to these changes almost on a consistent basis in order to sustain themselves. While the financial industry used to be described as a highly regulated sector in the past, armed with limited products and restricted by geographical expansion, today's situation of the financial industry has changed (Rasid \& Rahman, 2009; Laela, Rossieta, Wijanto, \& Ismal, 2018). Currently, financial institutions trade in various range of complex financial assets. They also have to respond to the mergers and the acquisition exercise's call between insurers, banks and asset managers, resulting in a complex business world. The deregulation practices caused by the effect of globalisation have additionally terminated the complacent approach financial institutions used to practice. In order to address this dynamic and uncertain environment in which today's business is involved in, financial institutions have had to undergo rapid transformation in order to gain a competitive advantage. These institutions need to search for a valuable strategic tool to help them to succeed, survive and be sustainable in these turbulent situations.

Literature (e.g. Simmonds, 1981; Nixon \& Burns, 2012; Turner, Way, Hodari \& Witteman, 2017) has emphasised on the application of strategic 
management accounting (SMA) as an important tool, that could be used to enhance decision-making. Within the financial service industry, the need for SMA lies in its ability to provide quality management information which help to signal problems posed by globalisation, thereby enabling the management to react swiftly in response to the challenges (Rezaee, 2005; Kafafian, 2001).

A review of the SMA literature (Turner et al., 2017; Bhimani \& Langfield-Smith, 2007, Cravens \& Guilding, 2001) highlighted that this field of study has grown tremendously within the last few decades with a wide ranging scope (Langfield-Smith, 2008) and entailing different subjects (e.g. marketing, operations, strategic management). Researchers (Carlsson-Wall, Kraus, \& Lind, 2015; Juras, 2014; Roslender \& Hart, 2010) have also attempted to look into individual techniques such as target costing, life-cycle costing, attribute costing, and others to see their effect on SMA. Nonetheless, there has been a relative neglect on research investigating the linkage involving business strategies, SMA usage and firm performance (Carlsson-Wall et al., 2015). Since its introduction into academia, scholars and practitioners have expressed doubts on the practicality of SMA (Juras, 2014; Roslender \& Hart, 2010). This is compounded by the lack of research to explain its practices in organisations. Within the limited empirical evidences of SMA as noted in literature, only a few have highlighted its adoption in the financial industry.

Motivated by this lack in research contributions, the current study aims to contribute to the knowledge by examining how transformational leadership, organisational learning and technological innovation can affect SMA and how in turn, it influences firm performance. In this study, strategic management accounting is defined as the provision and analysis of management accounting data involving a business and its competition. The outcome generated from using SMA can be used for developing and monitoring business strategies, particularly those related to the levels and trends of real costs and prices, volume, market share, cash flow, and proportions demanded of a firm's total resources (Simmonds, 1981). SMA also refers to the provision of information that can be used to support organisational decisions in the long run, which would eventually lead to organisational performance (Jones, 1988). SMA provides firms with external non-financial information as well as internally generated information. Both are relevant for assessing the firms' competitive position within an industry; it particularly emphasises on customers and competitors, as externally located objects of management 
accounting analyses. Firms with successful implementation of SMA are expected to have a superior performance in doing business.

This study aims to contribute to the management accounting literature in two ways. First, the study fills the research void by focussing on financial institutions which play a relevant role in a country's economic growth. Financial institutions channel surplus funds to deficit units to help the country to ease its economy. The economic health of a country's financial system is of great concern since the sector is prone to instability phases. Such instability phases can generate a sizeable negative spillover effect on the country. The shortage of management accounting research, therefore warrants focus. Second, this study aims to provide empirical evidence which can illustrate the extent to which some SMA tools are used to support organisational performance, the role of transformational leadership, organisational learning and technological innovations. Many studies (Baines \& Langfield-Smith, 2003; Chenhall, 2003; Ahmad \& Mohamed Zabri, 2015) that have attempted to examine the effectiveness of accounting and management control systems in organisations, have mainly adopted the contingency theory. These studies also include factors which are related to the environment, technology, size, organisational structure and culture, as their contingent factors. In comparison, there are few studies which have highlighted that a firm's ability to adapt, especially in a fastchanging environment, relies, to a great extent, on its people's thoughts, behaviours, 'good organisational culture' and 'excellent management teams' (Yang, 2015). This highlights the need to include other factors such as transformational leadership, organisational learning and technological innovations as antecedents to SMA implementation.

The remainder of this study is organised as follows. Section 2 highlights the literature review, the underpinning theory and the hypotheses development. Section 3 discusses the research methods. Section 4 reports on the results and offers some discussions and Section 5 concludes the paper by discussing the practical and theoretical contributions followed by future recommendations.

\section{Literature Review}

\subsection{Strategic Management Accounting (SMA)}

The ideology of strategic management accounting (SMA), was introduced by Simmonds (1981). It was developed based on the failure 
of traditional management accounting techniques in providing sufficient information to managers (Guilding, Cravens, \& Tayles, 2000). Simmonds (1981) then positioned SMA as a distinctive concept which offers a more external, long-term, forward-looking and strategic focus since it is associated with companies and customers as well as competitors and markets. Similarly, Tillman (2003) mentioned that SMA differs from traditional management accounting practice in a number of ways. For instance, SMA combines management, accounting and marketing within its strategic management framework. It focusses not only on competitors, but also on the competitive environment, moving towards strategic innovation which is outside the norm of traditional accounting. Some scholars such as Cravens and Guilding (2001) and Roslender and Hart (2010) looked at SMA as a combination of the traditional accounting practices with a more contemporary approach such as lifecycle costing, attribute costing, benchmarking, strategic cost analysis and value chain costing. Whilst these techniques may have been applied by management accountants independently, it is believed that the techniques, when used collectively, can serve as an SMA concept.

Researchers (Cinquini \& Tenucci, 2007; Roslender \& Hart, 2010; Juras, 2014) have attempted to explain the concept of SMA as an alternative to management accounting. Cinquini and Tenucci (2007), for example, found that SMA techniques such as attribute costing, customer accounting, strategic pricing and competitive positions were extensively used in the Italian context. They further highlighted four standout features: competitors, long-run, processes and customer orientation. Other studies (Šoljakova, 2012; Fowzia, 2011) attempted to review the SMA technique usage. For instance, Fowzia (2011) noted that some SMA techniques can influence the financial performance of a firm but the intensity of usage may vary among different countries. Šoljakova (2012), on the other hand, argued that SMA concepts are applicable in strategic management, with many of the techniques traced to the extended application of the traditional methods. Within the financial industry, Oboh and Ajibolade (2017) examined the practicality of SMA adoption in Nigeria. They found that SMA contributes significantly to strategic decision-making; it helps firms to gain a competitive advantage by increasing their market shares. However, Oboh and Ajibolade (2017) only offered some insights into the usage of SMA from the perspective of a developing country. Their study is limited in scope, as it did not attempt to look into the antecedents of SMA use and their impact on firm's financial performance as a whole. Apart from the study of Oboh 
and Ajibolade (2017), there are very few SMA studies looking at the financial and banking sector. Past studies (Pavlatos, 2015; McManus, 2013) have only offered a view into using business strategies and property size as precursors to SMA use. These studies are also diverse in background as they are from different industrial sectors, hence the different characteristics of the financial industry.

\subsection{Theoretical Framework and Hypotheses Development}

This study draws its interpretations from the contingency theory (Chenhall, 2003) and resource-based views. Contingency theory which is frequently used in research focussing on management accounting serves as an approach to examine organisational behaviours, where reasons are given to explain how contingent factors or contextual variables, such as technology, culture, organisational structure and external environment shape the design and functions of a firm. The underlying assumption of the contingency theory is that there is no single type of organisational structure to fit all organisations. Instead the effectiveness of the organisation depends on the compatible match between the contextual variables or contingent factors. Based on the underlying assumption that organisational activity is the product of the organisational context, this study then takes the stance that the contingency theory asserts that when there is an appropriate match between accounting activities and the contextual factors, the firm's organisational performance is likely to accelerate. Building upon the contingency theory, this study postulates that the contextual variables encompassing transformational leadership, organisational learning and technological innovations will lead to SMA usage, which in turn, enhances firm performance.

According to the resource-based views of the firms, the key to enhance a firm's performance is based on the firm's internal resources, which are valuable, rare and not easily imitated and substitutable (Barney, 2001). Firms seek to secure and practice permanent or semipermanent control over resources that can offer them competitive advantage over their competitors. As firms practice various levels of control over different resources, they would be unique from each other. Based on the resource-based views, SMA is regarded as a valuable source of the firm's competitive advantage and performance. More successful SMA implementations can explicitly drive firms to have greater performance. Figure 1 shows the conceptual model of the relationships. 


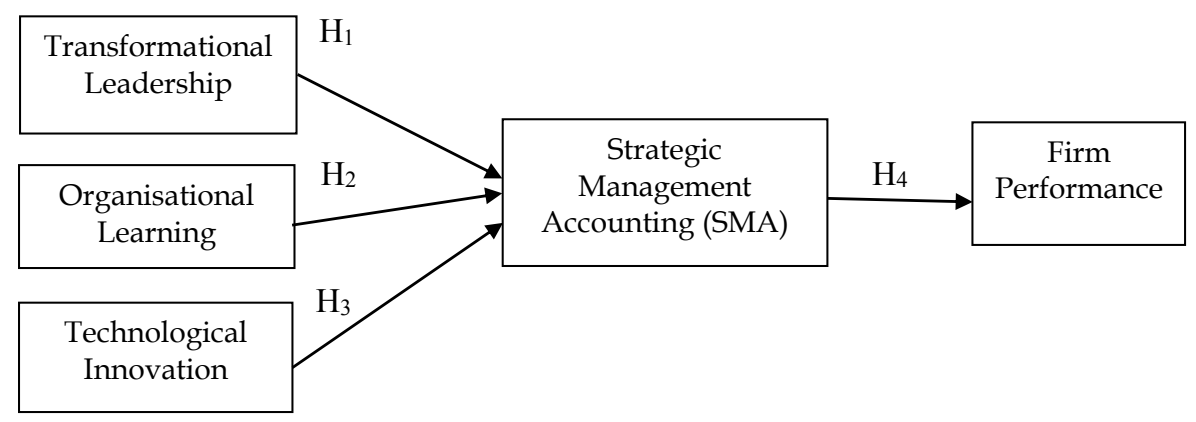

Figure 1: Conceptual Model of the Research Relationships

\subsubsection{Transformational Leadership}

Transformational leadership is the first antecedent of SMA. It refers to a particular leadership style that is likely to heighten consciousness of the collective interest among the organisation's members, helping them to achieve their collective goals (García-Morales, Jiménez-Barrionuevo, \& Gutiérrez-Gutiérrez, 2012). Transformational leadership is explicitly committed to the organisation's goals. It provides inspiration by motivating its followers to seek the best possible organisational performance. Firms with transformational leadership tend to focus on inspiring the values and ideals of employees, and ultimately, motivating them towards performance that is beyond expectations (Cho, Park, \& Michel, 2011). Transformational leadership consists of four behavioural components: idealised influence - holding high standard of morality, ethical and personal conduct, inspirational motivation - providing a strong vision for the future, intellectual stimulation - challenging organisation's norms and encouraging creative thinking, and individualised considerations - identifying and meeting employees' developmental needs (Jin, Seo, \& Shapiro, 2016). It is essential to provide employees with useful feedback, encourage them to make additional efforts to achieve novel solutions and to boost their intrinsic motivation to think creatively. Similarly, transformational leadership is defined as a set of behaviours that motivate employees to achieve performance that is beyond expectations by changing their attitudes, beliefs and values (Yucel, McMillan, \& Richard, 2014). Transformational leadership attempts to bring about higher levels of performance among individuals by influencing their goals and beliefs. Hence, transformational leadership has the potential to become a key driver for the successful 
implementation of SMA in an organisation. It could serve to enhance the firm's sustainable competitive edge and superior performance. Based on this, transformational leadership is likely to have a positive influence on strategic management accounting. The hypothesis thus formulated is:

\section{$\mathrm{H}_{1}$ : Transformational leadership has a positive relationship with strategic management accounting.}

\subsubsection{Organisational Learning}

Organisational learning is the second antecedent of SMA. It is defined as a continuous, dynamic and interactive learning process among individuals, groups, and organisations (Jiang \& Li, 2008). It is a vigorous process of creating, acquiring, generating, exploiting and transferring valuable knowledge through interaction, communication, interpretation and comprehension across partners. It is achieved by encouraging the firm's capacity to act and modify their behaviours which reflect new knowledge and insights. Firms which focus on organisational learning have the potential to transform the individuals who work in the organisation and transmit common knowledge into the system, structure and procedures used. By doing so, the firm and its members are equipped with a competitive advantage, thereby promoting superior performance, profitability and success. The main characteristic that reflects an organisation which is experiencing organisational learning is the people's acquisition of knowledge to solve the common problems faced. This is because organisational learning develops new knowledge which has the potential to influence behaviours involving the commitment to learn, be open minded and a desire to gain knowledge $(\mathrm{Hu}, 2014)$. Organisational learning is an important and basic organisational process through which information and knowledge can be processed. However, this can only be achieved through a change in the organisation's attributes, behaviours, capabilities and performance. Because of its benefits, organisational learning has been utilised by firms via knowledge acquisition, knowledge distribution, shared interpretations and organisational memory (Yu, Dong, Shen, Khalifa, \& Hao, 2013). This explains why it is critical to firms in helping them to maintain their survival and sustainability. Accordingly, organisational learning also supports creativity; it inspires new knowledge and ideas; it increases the ability to understand and to apply these ideas, thereby favouring organisational intelligence. Organisational learning also 
serves as the background for firms to implement their valuable strategies (Bolívar-Ramos, García-Morales, \& García-Sánchez, 2012). These strategies can be used to anticipate and understand customer needs and their competitors' strengths and weaknesses. As a result of that ability and knowledge, firms are able to generate greater organisational capabilities and results. In other words, organisational learning is likely to have a positive influence on SMA. Based on this, the hypothesis developed is:

$\mathrm{H}_{2}$ : Organisational learning has a positive relationship with strategic management accounting.

\subsubsection{Technological Innovation}

The last antecedent of SMA is technological innovation. It is a strategic potentiality to apply firm's usable and valuable actions, activities, operations and strategies to generate high firm performance (Camisón \& Villar-López, 2014). Technological innovation has a significant role in driving the firm's ability to compete and succeed in the rigorous markets. Technological innovation refers to firms' capacity to innovate and introduce new tools, instruments and processes of firms for the competitive market (Verdu, Tamayo, \& Ruiz-Moreno, 2012). Firms use this approach as a support for them to provide strategic flexibility and to enhance their profitability and success. Technological innovation is explicitly applied by firms through their existing technology in order to fill new market needs and to respond to environmental changes (Ratten, 2008). Consequently, technological innovation is an important driver of economic progress, productivity, growth and long-term performance within a complex market and environment. It enables firms to match technologies with market opportunities so as to generate a sustainable and competitive advantage as well as to promote their engagement and growth. To obtain prosperity in a dynamic environment, technological innovation has to be of two categories: exploitative innovation which concerns using current technological resource base and exploratory innovation which concerns searching and implementing new technological resource base (Wei, Yang, Sun, \& Gu, 2014). Both can be used by firms as a means to increase productivity and flexibility, thereby reducing cycle times and improving firm performance. Both these benefits can help the firm to apply strategic options, operations and practices which bring about competitiveness and greater firm outcomes, currently demanded by the uncertain markets and environment. 
Technological innovation is the key propelling successful strategic management accounting implementation. Due to this, technological innovation is likely to have a positive influence on SMA. Therefore, the hypothesis developed is:

$\mathrm{H}_{3}$ : Technological innovation has a positive relationship with strategic management accounting.

\subsubsection{Strategic Management Accounting}

As discussed earlier, transformational leadership, organisational learning and technological innovation are three main antecedents used for determining successful SMA implementation. In this study, SMA is taken to refer to the provision and analysis of management accounting data concerning a business and its competitors. SMA implementation can be used for the development and monitoring of business strategies (Simmonds, 1981). The three determinants proposed as antecedents of SMA can be a collective tool for firms to use their own business information to assess their competitive positions. SMA specifically emphasises on customers and competitors as the externally located objects of management accounting analyses. Therefore, more successful strategic management accounting implementation can be derived from the assessment. SMA also contributes to good decision making. In the provision of information that supports the firm's decisions in the long term, SMA also has a significant effect on firm performance (Jones, 1988; Turner et al., 2017). It is a technique that focusses on external and nonfinancial information as well as internally generated information. Firms have used SMA as the common-sense approach to deal with problems emanating from the ever changing, competitive and technological environment. Accordingly, SMA comprises three components: environmental scanning, competitor orientation and forward-looking information (Lachmann, Knauer, \& Trapp, 2013). These components reflect the firm's strategies in gaining a competitive advantage and performance. Firms with effective SMA implementation tend to have a sustainable and competitive advantage over others, thereby achieving a superior performance. As a result, SMA is likely to have a positive relationship with firm performance. Hence, the hypothesis developed is:

$\mathrm{H}_{4}$ : Strategic management accounting has a positive relationship with firm performance. 


\section{Research Methods}

\subsection{Sample Selection and Data Collection Procedure}

The samples retrieved for this study comprise 210 financial institutions that are listed on the Thailand Stock Exchange. They include banks, insurance companies, investment companies and security companies. As large organisations, these financial institutions also have many complex transactions, operations, activities, practices and actions. In this regard, strategic management accounting (SMA) would be most adequate to be used by these organisations to enable them to operate effectively and to succeed in highly complex situations and environment. In this study, data are collected by using a mail survey questionnaire. Prior to actual data collection, the questionnaire is first pilot tested with 30 respondents from the financial industry. The purpose of the pilot study is to examine the inconsistency of wording and the vagueness or ambiguity of items. Following feedback, the questionnaire is refined for the larger study.

The key informants for this study are accounting executives of financial institutions in Thailand. They also hold positions with the highest responsibilities involving accounting functions and other related activities in their organisations. Their positions thus include Chief Financial Officers, Accounting Directors or Accounting Managers. Of the 210 questionnaires mailed out, 147 were received, indicating a response rate of 70 per cent. Aaker, Kumar and Day (2001) indicated that a response rate that is greater than 20 per cent for a mail survey, with an appropriate follow-up procedure, is considered acceptable. The assessment of the non-response bias is centred on two different procedures: (1) a comparison of sample statistics and known values of the population such as firm age and firm capital, and (2) a comparison of the first and the second wave data, as recommended by Armstrong and Overton (1977). It is found that neither procedure show any significant differences, indicating that the non-response bias is not an issue. Table 1 outlines the demographic characteristics of these institutions.

According to the data shown, more than half or 59.18 per cent of the financial institutions have operated their businesses for 15 years or more. In addition, three quarters or 76.19 per cent of these financial institutions have 500 employees or more in their organisations, and more than half or 64.63 per cent of these institutions engaged in a firm capital of less than 10,000 million baht. 
Table 1: Demographic Characteristics of Financial Institutions in Thailand

\begin{tabular}{llcr}
\hline Descriptions & Categories & Frequencies & Percentage \\
\hline No. of operation & $<15$ years & 60 & 40.82 \\
$\quad$ periods & $=>15$ years & 87 & 59.18 \\
No. of full-time & $>$ 500 employees & 35 & 23.81 \\
employees & $=>500$ employees & 112 & 76.19 \\
Firm capital & $<10,000$ million baht & 95 & 64.63 \\
& $>=10,000$ million baht & 52 & 35.37 \\
\hline
\end{tabular}

\subsection{Measures}

All the constructs are measured using a 5-point Likert scale ( 1 = strongly disagree to $5=$ strongly agree), except for firm age, firm size, and firm capital. Measurements of these constructs are adapted from existing literatures. Table 2 presents the measurements of all the variables in this study.

The first of these is transformational leadership, which refers to the leadership style of leaders which helps to increase the consciousness of collective interest among members of the organisation, helping them to achieve their collective goals (García-Morales et al., 2012). The next variable is organisational learning which refers to the dynamic process of creating, acquiring, generating, exploiting and transferring valuable knowledge, through the interaction, communication, interpretation, and comprehension among partners. Organisational learning also refers to the firm's capacity to act and modify behaviours which can reflect new knowledge and insights (Jiang \& Li, 2008). The third variable is technological innovation, which refers to the firm's capacity to innovate and introduce new tools and instruments as well as the firm's processes so as to be competitive in the current market (Verdu et al., 2012). The fourth variable is SMA which refers to the provision and analysis of management accounting data regarding a business and its competitors. SMA can be used for developing and monitoring business strategies (Simmonds, 1981). The last variable is firm performance which refers to an outcome displaying the firm's competence and capability in practicing its business competitively (Cacciolatti \& Lee, 2016; Wang \& Sengupta, 2016).

Of the control variables, it is assumed that firm age (FA) may influence the firm's technological learning capacity, its implemented 
Table 2: Measurement of All Variables

\begin{tabular}{l|l}
\hline Variables and Items & S \\
\hline
\end{tabular}

Sources

Transformational Leadership (TL)

1. Our executives provide good business visions and policies for for gaining operational success.

2. Our executives continuously develop capabilities and competencies of employees in order to improve our efficiencies.

García-

Morales et

al. (2012)

3. Our executives explicitly invest an objectivity of information technology for attaining a goal achievement.

4. Our executives outstandingly support employees to learn and develop themselves continuously for promoting our competitiveness.

Organisational Learning (OL)

1. We believe that our employees have knowledge, competencies, skills, and responsibilities in helping achieve organisational success.

Li (2008)

2. We support exchange, coordination and working collaboration between teams that help make a decision quality.

3. We enhance employees to bring their best experiences for adjusting their practices and responsibilities in an organisation.

4. We concentrate systematic knowledge exchanges among employees for providing operational success.

\section{Technological Innovation (TI)}

1. Technology that has been continuously developed and improved affects best adjustment and learning development.

2. Growths of communication networks have supported businesses to operational efficiency.

3. Tools, operational processes and supporting systems that continuously occur can promote businesses to succeed.

4. Technology innovation that continuously occurs can enhance businesses to have a goal achievement.

Strategic Management Accounting (SMA)

1. We utilise the systematic and objective analysis of operational environments for effectively implementing management accounting in operations by gaining maximised benefits.

2. We emphasise the best understanding of competitor situations for presenting management accounting efficiently and effectively to the enterprises.

3. We apply current and future information in modernise, beneficial and capable aspects in promoting management accounting to become important tools in supporting the highest administrative goals. 
Table 2: continued

\begin{tabular}{l|l}
\hline Variables and Items & Sources \\
\hline $\begin{array}{l}\text { Firm Performance (FP) } \\
\text { 1. We have critically achieved the goal and objective settings. } \\
\text { 2. We have gained more profitability and market share than } \\
\begin{array}{l}\text { competitors. } \\
\text { 3. We have been recognised from stakeholders which we have } \\
\text { outstandingly developed our administrations. }\end{array} \\
\begin{array}{l}\text { 4. Our executives have satisfied our previous business outcomes } \\
\text { continuously. }\end{array}\end{array}$ & $\begin{array}{l}\text { Cand Lee } \\
\text { (2016); } \\
\text { Wang and } \\
\text { Sengupta } \\
(2016)\end{array}$ \\
\hline
\end{tabular}

business activities, actions and strategies as well as the profitability of its operations (Zahra, Ireland, \& Hitt, 2000). Firm age is measured by the number of years a firm has been in existence, by using a dummy variable as less than 15 years $=0$ and equal to or greater than 15 years $=$ 1. The next control variable is firm size (FS). It is also assumed that this may affect the firm's ability to learn and diversify its operations, and so compete and survive in the market (Arora \& Fosfuri, 2000). Firm size is measured by the number of employees in a firm by using a dummy variable where less than 500 employees $=0$ and equal to or greater than 500 employees $=1$. Finally, firm capital $(F C)$ is expected to impact the capacity of the firm to implement business methods and strategies in order to achieve a competitive advantage leading to superior performance (Ussahawanitchakit, 2007). Firm capital is measured by the amount of money a firm has invested in doing business by using a dummy variable, where less than 10,000 million baht $=0$ and equal to or greater than 10,000 million baht $=1$.

\section{Analysis and Discussion of Findings}

\subsection{Measurement Validation}

Factor analysis, using principal component analysis with varimax rotation, is performed to evaluate the construct validity of the variables used in this study. Prior to performing this, the Kaiser-Meyer-Olkin $(\mathrm{KMO})$ statistics are assessed to ensure that factor analysis is suitable for use. A value of 0.76 with $\mathrm{p}<0.001$ indicated that factor analysis is appropriate to be conducted (Kaiser, 1974). Table 3 presents the results for the factor loadings, item-total correlation and Cronbach's alpha for 
Table 3: Results of Measure Validation

\begin{tabular}{lccc}
\hline Items & $\begin{array}{c}\text { Factor } \\
\text { Loadings }\end{array}$ & $\begin{array}{c}\text { Item-total } \\
\text { Correlation }\end{array}$ & $\begin{array}{c}\text { Cronbach } \\
\text { Alpha }\end{array}$ \\
\hline Transformational Leadership (TL) & $0.69-0.87$ & $0.71-0.81$ & 0.74 \\
Organisational Learning (OL) & $0.65-0.80$ & $0.69-0.79$ & 0.75 \\
Technological Innovation (TI) & $0.83-0.87$ & $0.84-0.87$ & 0.87 \\
Strategic Management Accounting & $0.67-0.79$ & $0.61-0.82$ & 0.76 \\
$\quad$ (SMA) & & & \\
Firm Performance (FP) & $0.78-0.95$ & $0.78-0.95$ & 0.86 \\
\hline
\end{tabular}

the multiple-item scales used. In this study, factor analysis is conducted separately for each set of items representing a particular scale due to limited observations. As indicated by Table 3, the items loaded for each factor are greater than 0.4 and so, statistically significant (Nunnally \& Bernstein, 1994).

In this study, we also inspect the item-total correlation. It is found that all the items achieve the values of 0.61-0.95, which are greater than 0.30 (Churchill, 1979). The resulting scales are also evaluated using Cronbach's alpha coefficients. All the scales are found to have acceptable alpha values of greater than 0.70 (Nunnally \& Bernstein, 1994). Onetailed Pearson correlation is then employed to evaluate the predictive validity and to assure that the scales do not violate the multicollinearity issue. As shown in Table 4, all the independent variables are found to be significantly correlated with the dependent variable. All the independent variables are not highly correlated with each other. This result indicated that the multicollinearity effect is not an issue.

Table 4: Descriptive Statistics and Correlation Matrix

\begin{tabular}{lccccc}
\hline Variables & TL & OL & TI & SMA & FP \\
\hline Mean & 4.10 & 4.21 & 4.15 & 4.01 & 3.98 \\
Standard Deviation & 0.48 & 0.43 & 0.42 & 0.50 & 0.72 \\
Transformational Leadership (TL) & & & & & \\
Organizational Learning (OL) & 0.26 & & & & \\
Technological Innovation (TI) & 0.28 & $0.49^{* * *}$ & & & \\
Strategic Management Accounting (SMA) & 0.27 & $0.34^{* *}$ & $0.63^{* * *}$ & & \\
Firm Performance (FP) & 0.26 & 0.28 & $0.57^{* * *}$ & $0.54^{* * *}$ \\
\hline
\end{tabular}

Note: ${ }^{* *} \mathrm{p}<.05,{ }^{* * *} \mathrm{p}<.01$. 
A hierarchical multiple regression analysis is then conducted to examine the effects of transformational leadership, organisational learning and technological innovation on strategic management accounting; it also examines the relationships between strategic management accounting and firm performance. Because all variables in this study are neither nominal data nor categorical data, the hierarchical multiple regression analysis is an appropriate method for examining the hypothesised relationships. Table 5 presents the results of the hierarchical regression analysis showing the relationships among transformational leadership, organisational learning, technological innovation and strategic management accounting and also the relationships between strategic management accounting and firm performance.

Table 5: Results of Hierarchical Multiple Regression Analysis

\begin{tabular}{|c|c|c|c|c|}
\hline \multirow{2}{*}{$\begin{array}{l}\text { Independent } \\
\text { Variables }\end{array}$} & \multicolumn{4}{|c|}{ Dependent Variables } \\
\hline & SMA & SMA & FP & FP \\
\hline TL & & $\begin{array}{l}0.32^{* *} \\
(0.15)\end{array}$ & & \\
\hline OL & & $\begin{array}{c}0.24^{*} \\
(0.22)\end{array}$ & & \\
\hline TI & & $\begin{array}{r}0.30^{*} \\
(0.23)\end{array}$ & & \\
\hline SMA & & & & $\begin{array}{l}0.53^{* * *} \\
(0.14)\end{array}$ \\
\hline FA & $\begin{array}{c}0.02 \\
(0.14)\end{array}$ & $\begin{array}{l}-0.13 \\
(0.12)\end{array}$ & $\begin{array}{l}-0.10 \\
(0.14)\end{array}$ & $\begin{array}{l}-0.11 \\
(0.12)\end{array}$ \\
\hline FS & $\begin{array}{l}-0.01 \\
(0.13)\end{array}$ & $\begin{array}{l}-0.11 \\
(0.12)\end{array}$ & $\begin{array}{l}-0.06 \\
(0.13)\end{array}$ & $\begin{array}{l}-0.05 \\
(0.11)\end{array}$ \\
\hline FC & $\begin{array}{c}0.15 \\
(0.13)\end{array}$ & $\begin{array}{c}0.06 \\
(0.11)\end{array}$ & $\begin{array}{c}0.14 \\
(0.13)\end{array}$ & $\begin{array}{c}0.06 \\
(0.11)\end{array}$ \\
\hline Adjusted $R^{2}$ & 0.04 & 0.27 & 0.03 & 0.24 \\
\hline
\end{tabular}

Note: ${ }^{*} \mathrm{p}<.01,{ }^{* *} \mathrm{p}<.05,{ }^{* * *} \mathrm{p}<.001$, a beta coefficient with standard errors in parentheses.

\subsection{Regression Result}

In this study, the results show that transformational leadership is significant and positively linked to SMA $(\beta=0.32, p<0.05)$, hence $\mathrm{H}_{1}$ is supported. This is expected since transformational leadership 
provides employees with useful feedback, encouraging them to make additional efforts to achieve novel solutions, in addition to boosting their intrinsic motivation to think creatively for achieving performance that is beyond expectations. Under the transformational leadership, employees are encouraged to change their attitudes, beliefs and values, in order to achieve this high performance (Yucel et al., 2014). Therefore, transformational leadership can help firms with the successful implementation of SMA. Transformational leadership would stimulate and inspire the employees to accept the SMA as a way to solve problems and to challenge the status quo.

The findings generated from the analysis also show that organisational learning is positively associated with SMA $(\beta=0.24, p<0.01)$, thus $\mathrm{H}_{2}$ is supported. This implies that the successful implementation of SMA is dependent on the financial institution's ability to learn, absorb, adapt and apply the conceptual changes and also to integrate them within the organisation. Firms have utilised organisational learning through knowledge acquisition, knowledge distribution, shared interpretation and through the development of organisational memory (Yu et al., 2013). Employees' ability to learn new sets of skills that are related to the new and innovative accounting techniques, on a continuous basis, represents a sustainable source for the organisation to have a competitive advantage. Financial institutions with the learning focus will encourage their employees to provide feedback which enables the continuous improvement activities to be incorporated into the knowledge base of the employees.

The analysis of this study also noted that technological innovation has a significant effect on SMA $(\beta=0.30, p<0.01)$, hence $\mathrm{H}_{3}$ is supported. Considering that technological innovation is an important driver of economic progress, productivity growth and long-term performance in emerging economies such as Thailand, this result is not surprising (Wei et al., 2014). An earlier study conducted by Boonyanet and Komaratat (2008) and Nimtrakoon (2015) had shown that the use of contemporary management accounting practices which comprises the SMA is relatively low. In this regard, more technological innovation initiatives are needed to push for the usage of SMA in the financial industry of Thailand. Nonetheless, technological innovation may affect the design of the SMA used. For instance, technological innovations like enterprise resource planning (ERP) support the integration of both internal and external business processes, which have opened up a broader basis for management control. 
Similar with Turner et al. (2017), SMA is found to significantly affect firm performance positively $(\beta=0.53, p<0.01)$. In existing literature (Simmonds, 1981), SMA is shown to provide information that is relevant for firms to assess their competitive position within an industry. Clearly, SMA is a technique which stresses on external non-financial information and internally generated information for helping firms to make better decisions within an ever changing, competitive and technological environment. Firms that have successfully implemented the SMA are more likely to enjoy superior performance. Thus, it is not surprising that SMA is a key determinant of firm's performance.

\section{Contributions and Implications}

This study has attempted to investigate the antecedents that may influence the successful implementation of SMA and their effects on firm performance within Thailand's financial service industry. Using the contingency theory, this study has provided evidence to show that no single organisational design can be effectively applied universally. Three variables are incorporated to examine if they influence SMA and our findings indicate that transformational leadership, organisational learning and technological innovation contribute to the successful implementation of SMA among the financial institutions and that they also affect firm performance positively. Thus, this adds to the literature on SMA research.

The outcomes generated from this study also suggest that financial institutions in Thailand need to be more innovative and forward thinking in order to sustain themselves in today's competitive and turbulent environment. Specifically, they need to adopt innovative accounting management practices, which incorporate a broader scope of procedures involving informal, external and non-financial information, which are based on a long-term perspective and which are strategically oriented. As a part of the Asian region, Thailand has the potential to compete at the global level, especially with the integration of the ASEAN Economic Community (AEC) in 2015. Thus, Thailand needs to be aware of the new development of management accounting so that it can tap into its greater financial investments.

This study has explicitly identified transformational leadership, organisational learning and technological innovation as the valuable factors that affect successful SMA. The findings also show that to apply 
SMA, financial firms need to fine-tune their organisational culture, by cultivating transformational leadership. This is important as the current changing business environment requires a leader who is not only able to function as a manager who administers and controls but could also act as a catalyst for change. Such leadership styles clearly facilitate firm development by enabling it to maintain an innovative control system. This will further help the firms to promote divergent thinking, thereby creating new ideas. Financial institutions in Thailand, in their effort to implement SMA, should also leverage on organisational learning capabilities. Being equipped with this allows the financial institutions in Thailand to focus on providing new skills to their employees and to shift towards organisational learning, whereby knowledge can be captured and distributed. This will also enable the firms to apply the knowledge for enhancing organisational practices, including SMA.

The findings of this study highlighting the relevance of technological innovation reinforce the suggestion for supplementing SMA use with technology capabilities. The fact that technology has emerged to be one of the contributors accelerating changes in the business environment may allow us to extrapolate the importance of technology; it is an important aspect for the successful implementation of SMA. In fact, technological innovations when applied in the financial industry which uses modern technology and processes would propel SMA practices. In summary, to maximise the benefits and advantages of SMA implementation, it is evident that financial executives need to furnish their firms with the information on how transformational leadership, organisational learning and technological innovation can add value to their institutions.

While this study has important implications on the financial industry in a developing country like Thailand, it is not without limitations. First, the list of financial institutions identified for use in this study was self-collected from the Stock Exchange of Thailand and the Bank of Thailand. They include banks, insurance companies, investment companies and security companies. In this regard, there are possibilities that some of them may be listed officially but not detected by this study. Therefore, our findings could have been affected. Likewise, the background of the financial institutions may differ among themselves, but these too are not identified in the current study, hence it is possible that some variations may exist; these could also affect the implementation of the SMA. 


\section{Conclusion}

Existing literature shows that SMA is important for supporting firms in gaining a competitive advantage, superior performance, survival and sustainability, within the rigorous competitive market and environment. Accordingly, this study has examined the effects of transformational leadership, organisational learning and technological innovation on SMA implementation by the financial institutions of Thailand. This study also examines the relationships between SMA and firm performance. A total of 147 financial institutions are contacted via the mail survey questionnaire. Using a statistical analysis to project the findings, the results show that transformational leadership, organisational learning and technological innovation positively affected SMA. Similarly, SMA also has a positive relationship with firm performance. This implies that transformational leadership, organisational learning and technological innovation are the key determinants for successful SMA. It seems evident that SMA effectively drives positive changes in the firm's performance. To expand on the contributions of the current study, future research may need to collect data from different populations and countries so as to test the generalisability of the current study. Future research may also consider using a comparative study to test the research relationships and to search for a reliable database of financial businesses in Thailand in order to obtain a higher credibility of the findings.

\section{References}

Aaker, D.A., Kumar, V., \& Day, G.S. (2001). Marketing research (7th ed). New York, NY: John Wiley \& Sons. Inc.

Ahmad, K., \& Mohamed Zabri, S. (2015). Factors explaining the use of management accounting practices in Malaysian medium-sized firms. Journal of Small Business and Enterprise Development, 22(4), 762-781. http:// dx.doi.org/10.1108/JSBED-04-2012-0057

Armstrong, J.S., \& Overton, T.S. (1977). Estimating non-response bias in mail surveys. Journal of Marketing Research, 14(3), 396-402. http://dx.doi.org/ $10.2307 / 3150783$

Arora, A., \& Fosfuri, A. (2000). Wholly owned subsidiary versus technology licensing in the worldwide chemical industry. Journal of International Business Studies, 31(4), 555-572. http://dx.doi.org/10.1057/palgrave.jibs. 8490922

Baines, A., \& Langfield-Smith, K. (2003). Antecedents to management accounting change: A structural equation approach. Accounting, Organizations and Society, 28(7-8), 675-698. http:// dx.doi.org/10.1016/S0361-3682(02)00102-2 
Barney, J.B. (2001). Resource-based theories of competitive advantage: A tenyear retrospective on the resource-based view. Journal of Management, 27(6), 643-650. http://dx.doi.org/10.1177/014920630102700602

Bhimani, A., \& Langfield-Smith, K. (2007). Structure, formality and the importance of financial and non-financial information in strategy development and implementation. Management Accounting Research, 18(1), 3-31. http:// dx.doi.org/10.1016/j.mar.2006.06.005

Bolívar-Ramos, M.T., García-Morales, V.J., \& García-Sánchez, E. (2012). Technological distinctive competencies and organizational learning: Effects on organizational innovation to improve firm performance. Journal of Engineering and Technology Management, 29(3), 331-357. http://dx.doi.org/ 10.1016/j.jengtecman.2012.03.006

Boonyanet, W., \& Komaratat, D. (2008). Diversification of management accounting practices in the Thai listed companies. Chulalongkorn Business Review, 30(1-2), 116-134.

Cacciolatti, L., \& Lee, S.H. (2016). Revisiting the relationship between marketing capabilities and firm performance: The moderating role of market orientation, marketing strategy and organisational power. Journal of Business Research, 69(12), 5597-5610. http://dx.doi.org/10.1016/j.jbusres. 2016.03.067

Camisón, C., \& Villar-López, A. (2014). Organizational innovation as an enabler of technological innovation capabilities and firm performance. Journal of Business Research, 67(1), 2891-2902. http://dx.doi.org/10.1016/j. jbusres.2012.06.004

Carlsson-Wall, M., Kraus, K., \& Lind, J. (2015). Strategic management accounting in close inter-organisational relationships. Accounting and Business Research, 45(1), 27-54. http://dx.doi.org/10.1080/00014788.2014.965128

Chenhall, R.H. (2003). Management control systems design within its organizational context: Findings from contingency-based research and directions for the future. Accounting, Organizations and Society, 28(2-3), 127-168. http://dx.doi.org/10.1016/S0361-3682(01)00027-7

Cho, J., Park, I., \& Michel, J.W. (2011). How does leadership affect information systems success? The role of transformational leadership. Information $\mathcal{E}$ Management, 48(7), 270-277. http://dx.doi.org/10.1016/j.im.2011.07.003

Churchill, J.G.A. (1979). A paradigm for developing better measures of marketing constructs. Journal of Marketing Research, 16(1), 64-73. http://dx.doi. org $/ 10.2307 / 3150876$

Cinquini, L., \& Tenucci, A. (2007). Is the adoption of strategic management accounting techniques really "strategy-driven"? Evidence from a survey (MPRA Paper No. 11819). Munich: MPRA. Retrieved from https://mpra. ub.uni-muenchen.de/11819/1/

Cravens, K.S., \& Guilding, C. (2001). An empirical study of the application of strategic management accounting techniques. Advances in Management Accounting, 10(1), 95-124. 
Fowzia, R. (2011). Strategic management accounting techniques: Relationship with business strategy and strategic effectiveness of manufacturing organizations in Bangladesh. World Journal of Management, 3(2), 54-69.

García-Morales, V.J., Jiménez-Barrionuevo, M.M., \& Gutiérrez-Gutiérrez, L. (2012). Transformational leadership influence on organizational performance through organizational learning and innovation. Journal of Business Research, 65(7), 1040-1050. http://dx.doi.org/10.1016/j.jbusres.2011.03.005

Guilding, C., Cravens, K.S., \& Tayles, M. (2000). An international comparison of strategic management accounting practices. Management Accounting Research, 11(1), 113-135. http://dx.doi.org/10.1006/mare.1999.0120

$\mathrm{Hu}$, B. (2014). Linking business models with technological innovation performance through organizational learning. European Management Journal, 32(4), 587-595. http://dx.doi.org/10.1016/j.emj.2013.10.009

Jiang, X., \& Li, Y. (2008). The relationship between organizational learning and firms' financial performance in strategic alliances: A contingency approach. Journal of World Business, 43(3), 365-379. http://dx.doi.org/10.1016/j.jwb. 2007.11.003

Jin, S., Seo, M.G., \& Shapiro, D.L. (2016). Do happy leaders lead better? Affective and attitudinal antecedents of transformational leadership. The Leadership Quarterly, 27(1), 64-84. http://dx.doi.org/10.1016/j.leaqua.2015.09.002

Jones, L. (1988). Competitor cost analysis at Caterpillar. Management Accounting (US), 70(4), 32-38.

Juras, A. (2014). Strategic management accounting - What is the current state of the concept? Economy Transdisciplinarity Cognition, 17(2), 76-83.

Kafafian, R.E. (2001). Keys to community bank success: Utilizing management information to make informed decisions-types of management information. The Journal of Bank Cost \& Management Accounting, 14(1), 3-4.

Kaiser, H.F. (1974). An index of factorial simplicity. Psychometrika, 39(1), 31-36. http://dx.doi.org/10.1007/BF02291575

Lachmann, M., Knauer, T., \& Trapp, R. (2013). Strategic management accounting practices in hospitals: Empirical evidence on their dissemination under competitive market environments. Journal of Accounting \& Organizational Change, 9(3), 336-369. http://dx.doi.org/10.1108/JAOC-12-2011-0065

Laela, S.F., Rossieta, H., Wijanto, S.H., \& Ismal, R. (2018). Management accounting-strategy coalignment in Islamic banking. International Journal of Islamic and Middle Eastern Finance and Management, 11(4), 667-694. http://dx.doi. org/10.1108/IMEFM-04-2017-0088

Langfield-Smith, K. (2008). Strategic management accounting: How far have we come in 25 years? Accounting, Auditing \& Accountability Journal, 21(2), 204228. http://dx.doi.org/10.1108/09513570810854400

McManus, L. (2013). Customer accounting and marketing performance measures in the hotel industry: Evidence from Australia. International Journal of Hospitality Management, 33(June), 140-152. http://dx.doi.org/10.1016/ j.ijhm.2012.07.007 
Nimtrakoon, S. (2015). The relationship between intellectual capital, firms' market value and financial performance: Empirical evidence from the ASEAN. Journal of Intellectual Capital, 16(3), 587-618. http://dx.doi.org/ 10.1108/JIC-09-2014-0104

Nixon, B., \& Burns, J. (2012). The paradox of strategic management accounting. Management Accounting Research, 23(4), 229-244. http://dx.doi.org/ 10.1016/j.mar.2012.09.004

Nunnally, J.C., \& Bernstein, I.H. (1994). Psychometric Theory. New York, NY: McGraw-Hill.

Oboh, C.S., \& Ajibolade, S.O. (2017). Strategic management accounting and decision making: A survey of the Nigerian Banks. Future Business Journal, 3(2), 119-137. http:/ / dx.doi.org/10.1016/j.fbj.2017.05.004

Pavlatos, O. (2015). An empirical investigation of strategic management accounting in hotels. International Journal of Contemporary Hospitality Management, 27(5), 756-767. http:/ / dx.doi.org/10.1108/IJCHM-12-2013-0582

Rasid, S.Z.A., \& Rahman, A.R.A. (2009). Management accounting and risk management practices in financial institutions. Jurnal Teknologi, 51(1), 89110. http:/ / dx.doi.org/10.11113/jt.v51.159

Ratten, V. (2008). Technological innovations in the m-commerce industry: A conceptual model of WAP banking intentions. The Journal of High Technology Management Research, 18(2), 111-117. http:/ /dx.doi.org/10.1016/ j.hitech.2007.12.007

Rezaee, Z. (2005). The relevance of managerial accounting concepts in the banking industry. Journal of Performance Management, 18(2), 3-16.

Roslender, R., \& Hart, S.J. (2010). Strategic management accounting: Lots in a name? (Accountancy Discussion Papers, 1005). Edinburgh, Scotland: Heriot-Watt University.

Simmonds, K. (1981). Strategic management accounting. Management Accounting (UK), 59(4), 26-29.

Šoljakova, L. (2012). Strategic management accounting development during last 30 years. European Financial and Accounting Journal, 7(2), 24-35. http:// dx.doi.org/10.18267/j.efaj.8

Tillmann, K. (2003). Strategic management accounting and sense making: A grounded theory study (Doctorate thesis, University of Southampton, UK).

Turner, M.J., Way, S.A., Hodari, D., \& Witteman, W. (2017). Hotel property performance: The role of strategic management accounting. International Journal of Hospitality Management, 63(May), 33-43. http://dx.doi.org/ 10.1016/j.ijhm.2017.02.001

Ussahawanitchakit, P. (2007). The influences of management capability on export performance of leather businesses in Thailand. Review of Business Research, 7(5), 1-10.

Verdu, A.J., Tamayo, I., \& Ruiz-Moreno, A. (2012). The moderating effect of environmental uncertainty on the relationship between real options and 
technological innovation in high-tech firms. Technovation, 32(9-10), 579-590. http://dx.doi.org/10.1016/j.technovation.2012.06.001

Wang, H.M.D., \& Sengupta, S. (2016). Stakeholder relationships, brand equity, firm performance: A resource-based perspective. Journal of Business Research, 69(12), 5561-5568. http://dx.doi.org/10.1016/j.jbusres.2016.05.009

Wei, Z., Yang, D., Sun, B., \& Gu, M. (2014). The fit between technological innovation and business model design for firm growth: Evidence from China. RED Management, 44(3), 288-305. http://dx.doi.org/10.1111/radm.12069

Yang, C-C. (2015). The integrated model of core competence and core capability. Total Quality Management \& Business Excellence, 26(1-2), 173-189. http:// dx.doi.org/10.1080/14783363.2013.820024

Yu, Y., Dong, X-Y., Shen, K.N., Khalifa, M., \& Hao, J-X. (2013). Strategies, technologies, and organizational learning for developing organizational innovativeness in emerging economies. Journal of Business Research, 66(12), 2507-2514. http://dx.doi.org/10.1016/j.jbusres.2013.05.042

Yucel, I., McMillan, A., \& Richard, O.C. (2014). Does CEO transformational leadership influence top executive normative commitment? Journal of Business Research, 67(6), 1170-1177. http://dx.doi.org/10.1016/j.jbusres. 2013.05.005

Zahra, S.A., Ireland, R.D., \& Hitt, M.A. (2000). International expansion by new venture firms: International diversity, mode of market entry, technological learning, and performance. Academy of Management Journal, 43(5), 925-950. http://dx.doi.org/10.5465/1556420 